pulsatile growth hormone secretion in children after therapy for acute lymphoblastic leukemia. J Pediatr 104:182-186

23. Shalet SM, Beardwell CG, Twomey JA, Morris Jones PH, Pearson D 1977 Endocrine function following the treatment of acute leukemia in childhood J Pediatr 90:920-923

24. Brook CGD, Hindmarsh PC 1991 Tests for growth hormone secretion. Arch Dis Child 66:85-87

25. Caccani E, Taasoni P, Parisi G, Pirazzoli P, Zucchini S, Mandini M, Cicognani A, Balsamo A 1992 Pitfalls in diagnosing impaired growth hormone $(\mathrm{GH})$ secretion: retesting after replacement therapy of 63 patients defined as $\mathrm{GH}$ deficient. J Clin Endocrinol Metab 74:1284-1289

26. Shalet SM, Price DA, Beardwell CG, Morris Jones PH, Pearson D 1979 Normal growth despite abnormalities of growth hormone secretion in children treated for acute leukemia. J Pediatr 94:719-722
27. Zadik Z, Chalew SA, Gilula Z, Kowarski AA 1990 Reproducibility of growth hormone testing procedures: a comparison between 24-hour integrated concentration and pharmacological stimulation. J Clin Endocrinol Metab 71:1127-1130

28. Moëll C 1988 Disturbed pubertal growth in girls after acute leukemia: a relative growth hormone insufficiency with late presentation. Acta Paediatr Scand [Suppl] 343:162-166

29. Leiper AD, Stanhope R, Kitching P, Chessels JM 1987 Precocious and premature puberty associated with treatment of acute lymphoblastic leukemia Arch Dis Child 62:1107-1112

30. Otten BJ, Lippens RJJ, van 't Hof MA 1988 Growth and puberty in children with acute lymphoblastic leukemia. Acta Paediatr Scand [Suppl] 343:224225

\title{
Announcement
}

\section{American Board of Nutrition 1993 Examination}

In response to a high level of interest, the deadline for receipt of application, academic records, and sponsoring letters has been extended to July 1,1993 .

The next certifying examination of the American Board of Nutrition will be administered in Milwaukee, WI on the morning of Friday, October 15, 1993, before the Postgraduate Course jointly sponsored by ASCN, NAASO, and ADA.

Individuals with a doctoral degree (M.D. Ph.D., or equivalent) and an appropriate nutrition background are eligible to take the examination. M.D. candidates must be certified by a primary board recognized by the American Board of Medical Specialties and must have completed at least 2 years of appropriate nutrition training at the time of the examination, including 1 year of clinical experience. Ph.D. candidates must have at least 2 years of postdoctoral experience in human nutrition. In a new 4-hour format, there will be two written phases of the examination. Phase I will test broad knowledge of the fundamentals of nutrition, and Phase II will test the clinical applications of the knowledge.

For more detailed information, write or call: The American Board of Nutrition, 9650 Rockville Pike, Bethesda, MD 20814, (301) 530-7111. 